\title{
Minimalism in Art, Medical Science and Neurosurgery
}

\author{
Ali Ihsan OKTEN \\ Adana Numune Training and Research Hospital, Department of Neurosurgery, Adana, Turkey
}

\section{ABSTRACT}

The word "minimalism" is a word derived from French the word "minimum". Whereas the lexical meaning of minimum is "the least or the smallest quantity necessary for something", its expression in mathematics can be described as "the lowest step a variable number can descend, least, minimal". Minimalism, which advocates an extreme simplicity of the artistic form, is a current in modern art and music whose origins go to 1960s and which features simplicity and objectivity. Although art, science and philosophy are different disciplines, they support each other from time to time, sometimes they intertwine and sometimes they copy each other. A periodic schools or teaching in one of them can take the others into itself, so, they proceed on their ways empowering each other. It is also true for the minimalism in art and the minimal invasive surgical approaches in science. Concepts like doing with less, avoiding unnecessary materials and reducing the number of the elements in order to increase the effect in the expression which are the main elements of the minimalism in art found their equivalents in medicine and neurosurgery. Their equivalents in medicine or neurosurgery have been to protect the physical integrity of the patient with less iatrogenic injury, minimum damage and the same therapeutic effect in the most effective way and to enable the patient to regain his health in the shortest span of time. As an anticipation, we can consider that the minimal approaches started by Richard Wollheim and Barbara Rose in art and Lars Leksell, Gazi Yaşargil and other neurosurgeons in neurosurgery in the 1960s are the present day equivalents of the minimalist approaches perhaps unconsciously started by Kazimir Malevich in art and Victor Darwin L'Espinasse in neurosurgery in the early 1900 s. We can also consider that they have developed interacting with each other, not by chance.

KEYWORDS: Minimalism, Art, Neurosurgery, Medicine

\section{INTRODUCTION}

$\mathrm{T}$ The main philosophy of minimalism is "Do not tell more than you need to tell and do not show more than you need to show." Minimalism, which advocates an extreme simplicity of the artistic form, is a current in modern art and music whose origins go to 1960s and which features simplicity and objectivity. It is also referred with terms such as ABC Art and Minimal Art $(3,5)$. Kazimir Malevich gave the first signal of minimalism in 1915 with the painting he made putting his "Black Square" on a white background (4). This line started by Malevich can be considered as the beginning of Minimalism which was effective especially in America in the 1960s and 1970s. Malevich demolished the acceptances of his time which never went beyond the colours and form imposed by the nature and he formed an idiosyncratic language (Figure 1). The understanding of minimal architectural form reduced to rectangular prisms by the architect Mies van der Rohe (7) with his plain designs in architecture in the same years compromises with the minimal understanding of art (Figure 2). This line started by Malevich and van der Rohe were conceptualized by a group of artists, architects and sculptors who were efficient especially in America in 1960s and 1970s and they defined "Minimalism" with the works of art they created.

The term Minimalism is presumed to be used by Richard Wollheim in the magazine "Art Magazin" in 1965 for the first time (6). According to another opinion, the first use of the term was in the article titled "ABC Art" by Barbara Rose published in the October 1965 issue of the magazine "Art in America" (3). A new inclination of art was mentioned in this article and when a naming like ABC Art was not internalised, the word "minimum" used in the same article was started to 
be used as the concept of "minimalism/minimal art. Besides characterizing the forms of art, especially music and visual art, the term would be a new current in art which would be considered as the continuation of the Bauhaus school but later evaluated within the postmodern understanding of art. It brought a new philosophy of art, aesthetic understanding and conceptualization to art (5).

\section{- THE PHILOSOPHY of MINIMALISM in ART}

Generally, each current in art is born as a reaction against the previous current. The birth of Minimalism is a reaction against the excessive importance of emotions and format in art. However, it is an understanding of art which has matured interacting with them like the previous currents in art. The common feature of the currents in art which leaded it to be born was their being fed from formations such as realism, objectivity, functionality and simplicity. After the Enlightenment in the Renaissance era, the change and the technical developments in manufacturing caused the industrial revolution. The human being who met the industry and the machinery for the first time had to set a new World order and a new reality after the war. The birth of modernism is in reality a result of this depressed and complicated period. Everything became "meaningless" in Dadaism and "meaningless reality" in Surrealism. America's flourishing and investing in the artistic environment created the fact of art as a commodity and an object. At the end of the 1960s, a group of young artists decided that they needed to use images which would be explained by the society easily in order to break off the daily monotonous and crowded life, except this situation. The boring crowd which was started to be created by the growing technology and the society which began to get tired when they faced all of these formations growing rapidly gave birth to pop art after expressionism. Pop art tries to bring what is daily into art. The emerging philosophy of the Minimal Art is to redound a new point of view which is not based on consumption culture after pop art in visual arts (5). Why was it needed? The intention is to abolish the incomprehensibility felt by the audience. It is a serious aesthetic change even it is not radical. Perhaps, the main reason is the desire to scatter the boring crowd started to be created by the growing technology. Because, the societies began to get tired in face of all these rapidly growing formations. Of course, the noise made by this speed was making people surprised and stressed. The remedy for this stress was minimalism with its calm structure advising to think (7). Minimalism also started to coincide with the philosophy of art more. The houses people in this intensive tempo lived, the music they listened to, the films or plays they watched and the paintings and photographs they saw at exhibitions should stay far away from the chaos in the outer World. Minimalism strongly advocates the theory stating that everything should be as they are seen. Not to include illusions and even to consider illusion as immoral and not to ascribe any expression to anything other than what they have are the main principles the style strongly depends on. Art and the human being should get rid of the excesses, unimportant details, worthless sides and the primary elements; they should get purified of them and do with less, more basic, essential and primary elements (Figures 2-4) $(5,6)$.
Minimalism means primarily to do with less, to start the journey with the limited means owned and to try to constitute the work within this frame. Minimalists intend to reduce the historical, symbolical and expressional meanings of the subject to the minimum. Minimalism is a reaction against formalism. The detection attributed to Immanuel Kant explains minimalism in an extremely comprehensible way: "Minimalism is a style, it uses reduced objects and elements." (1). If you do not have the financial power to present economically, it is an inevitable situation to descend to the basic elements. Although the

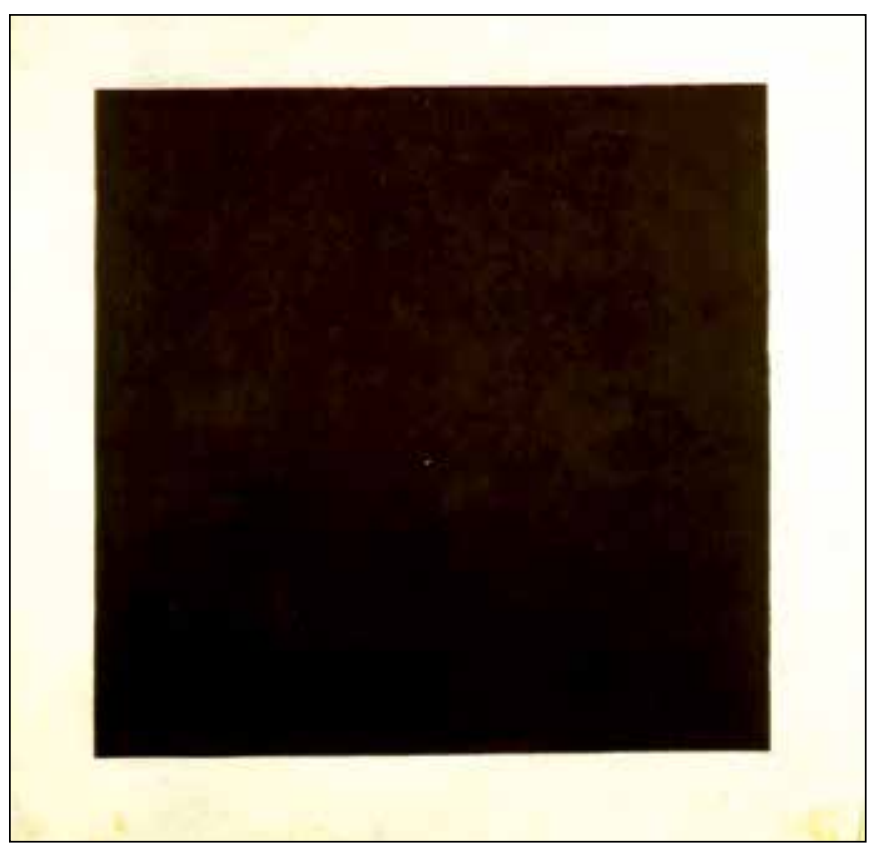

Figure 1: Kazimir Malevich's work named "Black Square" which he painted on a white background is extremely plain and striking. In this work, everything the viewers like and they are accustomed to see disappear and they transform into nothingness.

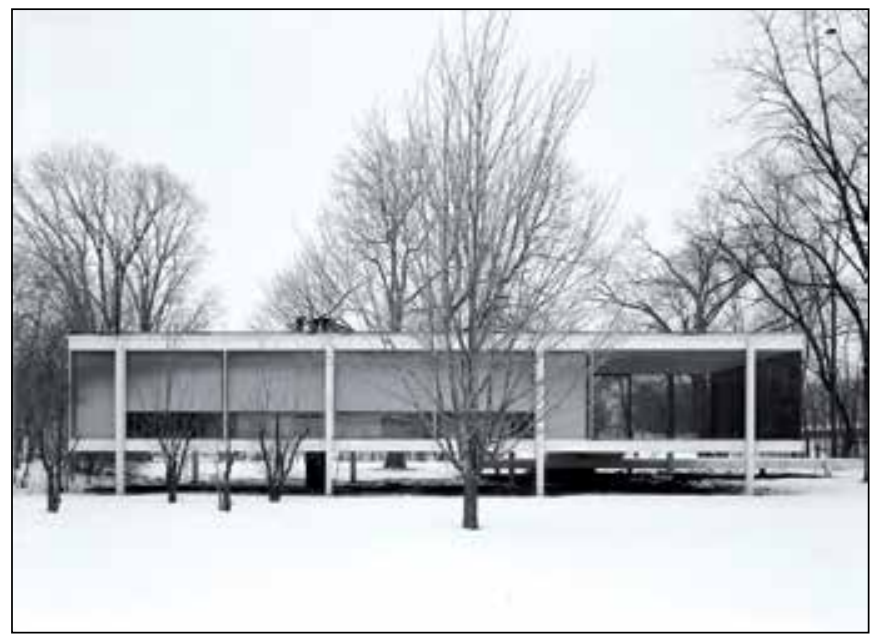

Figure 2: Mies van Rohe's "Farnsworth House" he designed with his understanding of architectural form he reduced to rectangular prisms. 
number of the elements is decreased, their content should not be reduced, and on the contrary, they should be protected in order to increase the effect in the expression. Reducing the colour and the form to the minimum, even drawing from the own colour of the material used and purifying the works from the expressions ascribed to the compositions, has been the basic attitude of the Minimalists. Many artists have defined their works as "nameless" in order to purify them from any kind of identity and the details and secondary elements are decreased all the way and an attempt is made to ascertain the main element (6).

\section{THE PHILOSOPHY of MINIMALISM in SCIENCE}

Art is the expression and practice of human creativity and surgery is the treatment of wounds or disorders in the body by cutting or directing by hands with tools with special characteristics $(8,9)$.

Throughout history, science supported art and art supported science. When science got away from art or philosophy, it lost its strength for developing and renewing itself. The minimalist current developed in art showed itself also in science in a short time. The minimalist current in art also showed itself in science. It developed commonly with practices such as minimal invasive medicine and minimal invasive surgery, commonly developed with practices such as endoscopy, robotic surgery, navigation and monitoring methods. Although the processes are minimally invasive procedures, all of these processes necessitate using complicated devices. The purpose in minimal invasive surgery is not only making a minimal skin incision, but also reducing the formation and recovery of iatrogenic injuries to the minimum (10). It is not only using minimal equipment or devices. When it is regarded from this point of view, the first minimalist physician in the history should be Hippocrates, who diagnosed a liver abscess using minimum tools and technology approximately 2500 years ago (17).

Minimalist approaches started to come into prominence also in science in an increasing way. Development of the medical devices with the developing technology shortened the operation times, increased the comfort of the patients and enabled the patients to recover in a shorter time and stay at the hospital for a shorter time (16). Many patients are discharged from the hospital on the same day just after the operation or the day after the operation. Now, it is possible to enter into the whole abdomen, shoulder, knee, brain or the thoracic cavity from 1 or $2 \mathrm{~cm}$ holes and all kinds of operations are made via the pipes inserted from these holes very successfully. These minimalist practices in medicine are named "minimal invasive approaches" (11-14). The main philosophy in this approach is to have maximum benefit with minimum harm. This minimalist way of approach called keyhole operations provides great conveniences for the surgeon and it is more comfortable for the patient at the same time (Figure 5). The patients have less pain, they are more comfortable during their recovery periods after the operation and they return to their work and continue their lives in a very short time.
It will be useful to indicate these differences between minimalism in art and minimalism in science. Whereas minimalist art is desired to be made with a minimal economy, minimalist surgery develops in consequence of serious economical

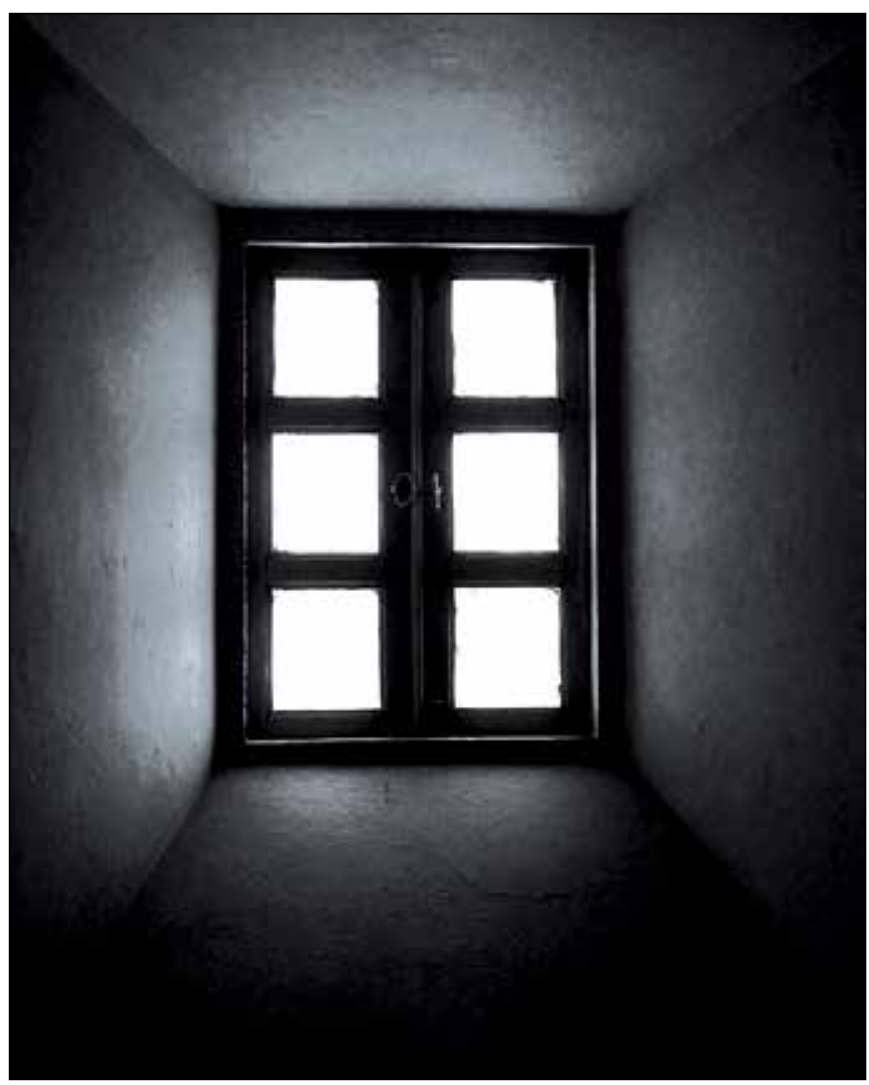

Figure 3: Prakash Gai's minimalist photograph named "The Window". A minimalist photograph consists of few elements; the composition should be simple, it should be easy to view but it should express much.

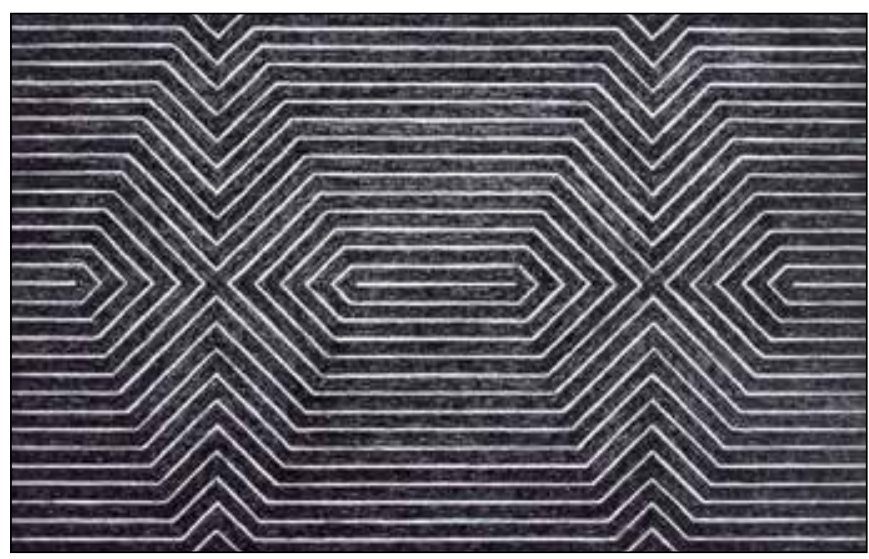

Figure 4: Minimalist paintings are works with a plain geometrical design where a few scanty colours are used. Frank Stella, who is considered as one of the pioneers of minimal art, highlighted the shape of the canvas with black and white lines in his work he named "Black Pictures", then he made different works in the shape of the canvas with the colours of the lines. 
expenses and it can be practices in consequence of these expenses. A minimalist work of art will remain as a minimalist work of art even after millions of years. However, a minimal invasive method or minimal surgery will lose this title of its in a short span of time as a result of the advances in medicine, as a dialectical rule. For example, an endoscopical operation will be named an operation more minimalistic than microsurgery. The purpose of science is to make progress in terms of treatment ways, patient comfort, cost and treatment time.

Until the late $20^{\text {th }}$ century, almost every surgical operation necessitated quite large cuts of the parts to be worked on. This operation usually consisted of cutting the skin and the tissues under the skin, the fascia on the muscle layer and the muscle layers under them, then the peritoneum in the abdomen or the pleura in the chest. It consisted of cutting the joint spacing in the joints and the layers surrounding the organ spaces such as the skull or the cerebral mantle for the brain. In order to reach the part to be operated, it was necessary to reach the organ and cut it. The surgical cuts were made large because of this reason. Although these methods are still used in the operations today, the operations can be made through the natural ways necessitating no cuts or with cuts so small that only the endoscope can enter, thanks to the minimalist approaches and the advanced endoscopic devices improving every day. The old understanding "a great surgeon opens a large cut" has become the contrary today.

Minimalistic approaches in the medical science started with the introduction of the fiberoptic devices with which endoscopic surgical procedures are made. Use of the fiberoptic materials in endoscopes made a great revolution in clinic gastroenterology first and then they entered into the concern of pulmonary medicine, general surgery, orthopedics, otorhinolaryngologic diseases, urology, neurosurgery and many other branches of medicine and this advancement brought a new dimension to surgical approaches. Since the light is transmitted by the fiberoptic system in the endoscope in a better way without any loss, the vision obtained is clearer and it is more realistic. Many surgical materials used for operations such as scissors, forceps, bipolar, cautery, stent, balloon dilator and laser knife can pass through the thin canals in these devices. Thus, the tools used here can also be used just like the microsurgery tools and more minimal invasive surgical procedures can be made. Thanks to the endoscopes, there is no need for retractors to reach the tissue now. The hands of the surgeon are outside the patient's body. Moreover, in robotic surgeries now, the hands of the doctor are farther and they command these devices. Thanks to these technics developed, the patients can recover in a shorter time and they can return to their work and the surgery scars and risk of infection are reduced to the minimum (Figures 6-8) (14).

\section{MINIMALISM in NEUROSURGERY}

We can start the history of the minimal invasive surgical procedures in neurosurgery with the choroid plexus excision on the hydrocephalic neonate made by Victor Darwin L'Espinasse in 1904 with a pediatric cystoscope. The stereotaxic tool developed by Lars Leksell in 1949 enabled the number of the

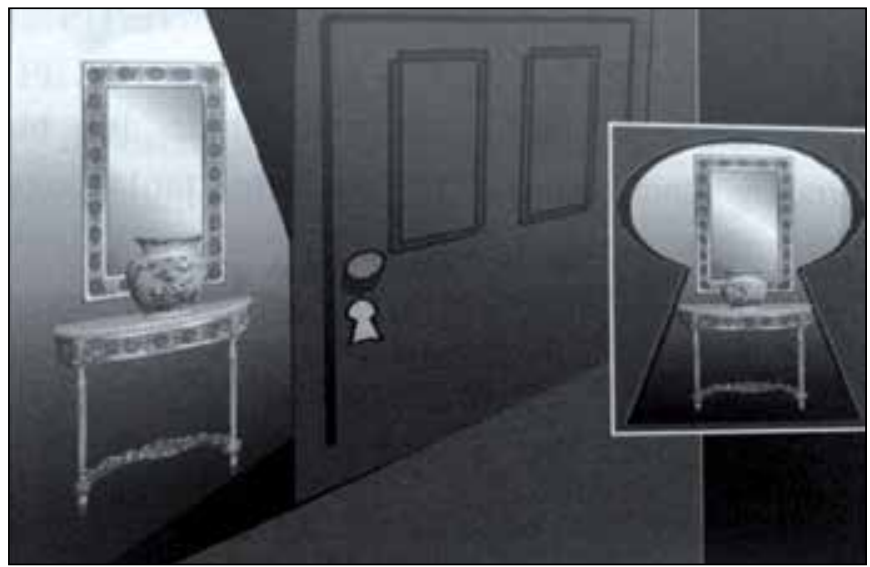

Figure 5: The basic mechanism of endoscopy is to provide a large and clear area to work using a small window.

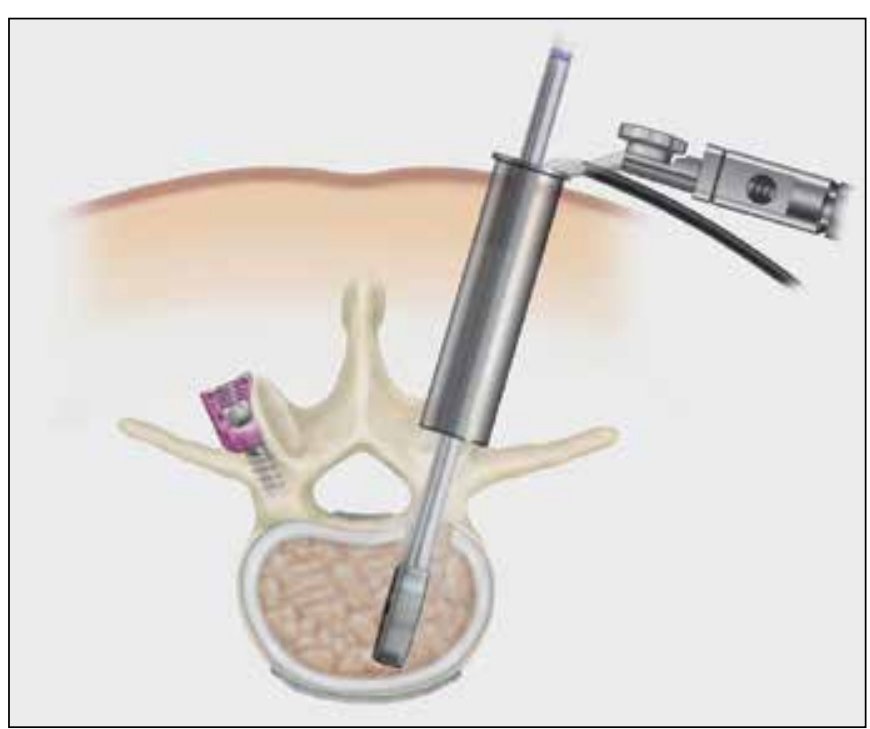

Figure 6: Stabilization can be provided in percutaneous instrumentation and fusion with $1 \mathrm{~cm}$ skin incisions.

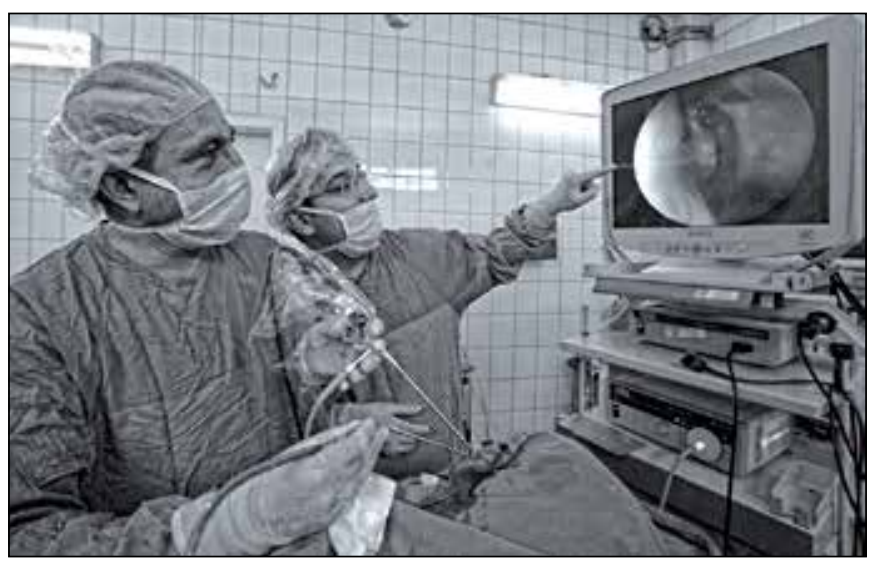

Figure 7: By endoscopical approach, it is possible to enter all of the spaces in the body through natural ways or 1 or $2 \mathrm{~cm}$ holes and reach the anatomical area with minimum trauma. 
minimal invasive procedures in brain surgery to increase (12). The microscope and microsurgery tools started to be used in brain and disc surgery by Prof. Gazi Yaşargil in 1960s created a revolution in neurosurgery and other surgical disciplines in terms of minimal surgical approaches (Figure 9) (10). In 1975, Hijikata used fluoroscopy which formed the base of minimal invasive surgery in the spine and he defined the percutaneous discectomy technique this way $(11,13,14)$. In the 1990 s, there were great advancements in terms of minimalist approaches in brain surgery with the development of neuronavigation, causing less damage in the tissues.

\section{CONCLUSION}

Although art, science and philosophy are different disciplines, they support each other from time to time, they sometimes intertwine and sometimes they copy each other. A periodic school or teaching in one of them can take the others into itself and they proceed on their ways empowering each other. Minimalism in art and the minimal invasive surgical procedures in science have been like this. The purpose of medicine is to cure the patient. The advances in science and technology and education activities have the same meaning: It is to reach aftercare in a short span of time considering providing the patient comfort with the lowest cost. Minimal invasive surgery intends to form smaller surgical scars, to decrease the risk of infection and to discharge the patient from hospital for him to return to his work earlier, one of the most important aspects it observes is minimal cost in terms of both health expenses and employer. While the minimalism in art puts the human being in the center through the artist's performance, minimalism in medical sciences puts the human being in the center in terms of treatment methods, patient comfort, treatment cost and time, through doctors. Concepts like doing with less, avoiding the unnecessary elements, reducing the number of the elements in order to increase the effect in the expression and being more economic, which are the main elements of the minimalist current in art, have found their equivalents in science. Their equivalents in science are protecting the physical integrity of the patient with minimum damage in the most effective way and enabling the patient to recover in the shortest time.

Surgery is considered an art, especially in medical sciences. There are medicine, art and philosophy following each other in it. It can be said that the meeting of science, art and philosophy which have become distant for a long time around the concept of minimalism again has made contributions to the development of the minimal invasive surgical procedures, a new concept in terms of neurosurgery. As an anticipation, we can consider that the minimal approaches started by Malevich in art and Victor Darwin L'Espinasse in science in the beginning of 1900s and the minimal approaches started by Richard Wollheim and Barbara Rose in art and by Gazi Yaşargil in science in the 1960s, their present equivalents, developed influencing each other, not by chance.

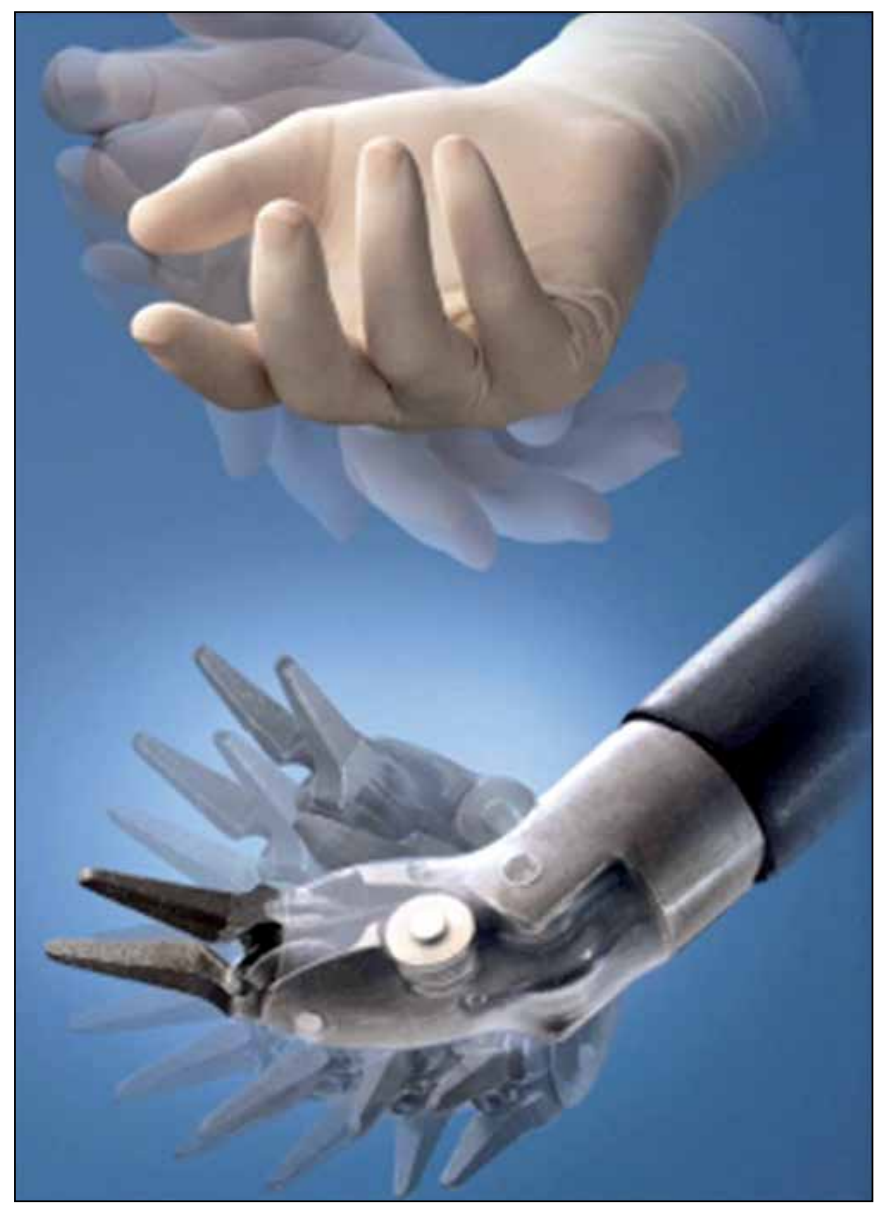

Figure 8: In robotic surgery, now the hands of the surgeon are completely outside the patient, and they command the robot.

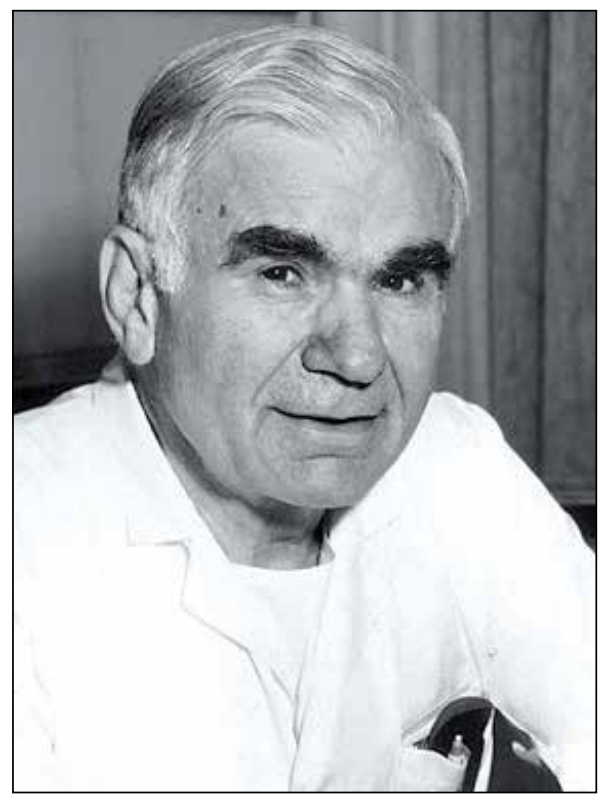

Figure 9: Prof. Dr. Gazi Yaşargil have used microscope in neurosurgery. He has been a pioneer in the development of minimally invasive approaches for developing microsurgical methods. 


\section{- REFERENCES}

1. Azarbad N: www.msxlabs.org/forum/sanat/14394-sanatakimlari-minimalizm-minimal-sanat.html (In Turkish)

2. EroğluÖ:www.fotoritim.com/minimalist-sanat/p/2514515256/ 2012/08/27/ozkan-eroglu--minimal-art-minimalizm (In Turkish)

3. https://en.wikipedia.org/wiki/Barbara Rose

4. https://en.wikipedia.org/wiki/Kazimir Malevich

5. https://en.wikipedia.org/wiki/Minimalism

6. https://en.wikipedia.org/wiki/Richard Wollheim

7. https://miessociety.org/legacy/projects/Mies van der Rohe Society | Projects

8. https://www.oxforddictionaries.com/definition/english/art

9. https://www.oxforddictionaries.com/definition/english/ surgery

10. lacoangeli M, Nocchi N, Nasi D, Di Rienzo A, Dobran M, Gladi M, Colasanti R, Alvaro L, Polonara G, Scerrati M: Minimally invasive supraorbital key-hole approach for the treatment of anterior cranial fossa meningiomas. Neurol Med Chir (Tokyo) 56(4):180-185, 2016
11. Khoo LT, Ozer AF, Cosar M, Asgarzadie F: History of minimally invasive spine surgery. http://www.turknorosirurji.org.tr/ TNDData/Books/338/history-of-minimally-invasive-spinesurgery.pdf

12. Leksell L: A stereotaxic apparatus for intracerebral surgery. Acta Chir Scand 99: 229-233, 1949

13. Sadahisa H: Percutaneous nucleotomy. A new concept technique and 12 years' experience. Clin Orthop Relat Res 238: 9-23, 1989

14. Sasani M, Özer F: Spinal minimal invaziv cerrahi yöntemler. Temel Nöroşirürji. Vol: 2. Ankara: Türk Nöroşirürji Derneği Yayınları, 2010: 1437, (In Turkish)

15. Serdar M: Yirmi film yirmi deneme. İstanbul: Sözcükler Yayınları, 2011 (In Turkish)

16. Straus EW, Straus A: Tıbbi mucizeler. Domingo Yayınları: 237, 2009 (In Turkish)

17. The Genuine Works of Hippocrates. Vol: 1, 2. Transl [from the Greek with a preliminary discourse and annotations]. New York: William Wood \& Co., 1886:57,58,266,267 